The Journal of Animal \& Plant Sciences, 30(3): 2020, Page: 663-676

ISSN (print): 1018-7081; ISSN (online): 2309-8694

\title{
DOES TECHNICAL PROGRESS MITIGATE CLIMATE EFFECT ON CROPS YIELD IN PAKISTAN?
}

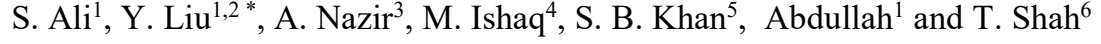 \\ ${ }^{1}$ College of Economics and Management Huazhong Agricultural University, No.1, Shizishan Street, Hongshan District, \\ Wuhan 430070 P.R China. \\ ${ }^{2}$ Hubei Collaborative Innovation Center for Grain Industry, Yangtze University, Jingzhou 434025, China. \\ ${ }^{3}$ Department of Agricultural Economics, Sindh Agriculture University, Tando Jam 70060 Pakistan. \\ ${ }^{4}$ Agricultural Pricing and Trade Policy, Social Sciences Division, Pakistan Agricultural Research Council, Islamabad. \\ ${ }^{5}$ Department of Animal Health, The University of Agriculture Peshawar, Khyber Pakhtunkhwa, Pakistan. \\ ${ }^{6}$ Department of Economics and Development Studies, University of Swat, Khyber Pakhtunkhwa 19130, Pakistan. \\ Corresponding Author‘s E-mail: liuyhzau@gmail.com;
}

\begin{abstract}
Efforts to sustain the global food system are suffering from the serious challenge of agricultural vulnerability to climate change. The current study is aimed at exploring the relation among yields of major food crops (wheat, rice and maize), climate change (temperature and rainfall), and technical progress (fertilizer and agricultural machinery) in Pakistan. In this regard, Autoregressive Distributed Lag (ARDL) model is employed using time series data over a period to time 1989 to 2015. To determine the co-integration, bound F-test results validate equilibrium for a long-run and short-run between yields of major food crops, temperature, rainfall, fertilizer and agricultural machinery. The long-run estimates indicate that area and temperature have a significant yet found a negative impact on wheat yield. However, for wheat yield, the coefficient of fertilizer usage was positive and had a significant effect. For rice crop, the coefficient of rainfall was found negative and had a statistically significant effect. The study concludes that climatic factors have a moderately negative impact on the yields of major food crops. The technical instruments and machinery needed to be enhanced since it plays an important role in increasing the yields of the crops. To deal and mitigate the negative effects of climate change, the government needs to develop agricultural adaptation policies, improve irrigation facilities and introduce high yielding and disease-resistant varieties for these food crops to ensure food security in the country.
\end{abstract}

Keywords: Climate change, technical progress, crops yield, ARDL model, Pakistan. https://doi.org/10.36899/JAPS.2020.3.0079

Published online March 25, 2020

\section{INTRODUCTION}

Climate change has direct and disastrous effects on agriculture segment since it specifically relies upon weather variability (Meza and Silva, 2009). The climatic intensity effect is determined by rainfall levels, patterns of temperature, the natural tolerance parameters for crops, the income per capita, the economic activities fraction those related to agriculture and pattern of employing of existing land (Benhin, 2006). Researchers including (Kurukulasuriya, et al., 2006; Tao, et al, 2006; Tao, et al., 2008; Webb et al., 2008; Whetton, and Barlow., 2008; You, et al., 2009; Deressa, et al., 2011; Özdoğan, 2011; Tao, et al., 2012; Potgieter, et al., 2013; Fatuase, 2014; Tao, et al., 2014; Gömann, 2015) and many others have shown that climate change poses threats to agriculture, food and water supplies especially in the developing economic settings. In South Asia, production of cereal crops is already under heat stress. Researchers predict that climate variations do adversely affect wheat yield in South Asia. According to (IPCC, 2007), in South Asia, crop yields might reduce up to 30 percent by 2050s. Being a South Asian country, Pakistan is not an exception, the vulnerability index of climate change in the country is quite high. The country is enlisted among the countries severely affected by climate change (Smadja, et al., 2015) despite low producer of $\mathrm{CO}_{2}$ gasses (Yousuf, et al., 2014) because of its increasing requirement on agriculture for food and fiber needs (Ahmad, et al., 2015) In short, Variations in climate stances severe threat to Pakistan by menacing its nutrients, water and energy security owing to a possible disparity in the meteorological condition patterns, severe happenings such as drought, heatwaves, floods and ultimate reduction of agricultural output. In addition, the majority of agriculture sector of Pakistan consists of small resourceless poor farmers with less adaption capacity. For the production of major food crops in Pakistan, climate change is expected to shrink the length of growing season (Ahmad et al., 2015). Annually, the US \$ 6-14 billion is required to curtail the devastating spells of the climate shift in Pakistan.

Climate change will affect crop productivity, and can thus cause food security problems (Kirby et al., 2016; Spash, 2007a, 2007b). Therefore, the major impact 
of climate change is on agricultural production due to changes in rain patterns, temperature, floods, droughts, and negative effects on water and land resources (Kurukulasuriya, et al., 2006; Mendelsohn, 2014). In the developing states (such as Asia and Africa), the latest work has progressively considered the impacts of climate change on agricultural production (Kurukulasuriya, et al., 2006; Mendelsohn, 2014). Studies reveal that increasing temperature and the changing pattern of rainfall have a substantial impact on food production (Janjua, et al., 2010; Mahmood, et al., 2012; Kirby et al., 2016). A recent study anticipates that the wheat production of South Asia will decline by $50 \%$ by 2050 equal to almost $7 \%$ of the global crop production (Fraiture, et al., 2007). Hence, climate change causes serious threats to food security (Doll and Siebert, 2002; Barnett, et al., 2005; Alcamo, et al., 2007; Spash, 2007a), negative impacts on productivity of different crops, the food supply (Arnell, et al., 2004; Rosenzweig and Parry, 1994), and the cost of adoption of climate change is high (Kandlikar and Risbey, 2000).

Of late, Pakistan has invariably confronted with spells of climatic variations, for instance, an extreme drought of 1999-2003, cyclones in Karachi/Gwadar in 2008 that resulted in the Glacial Lake Outburst Floods (GLOFS) and caused landslides in the Northern Pakistan and devastating floods of 2010, 2011 and 2013. Owing to varying climatic conditions assuring food security for the rapidly shooting population of the country is an immense challenge (Ahmad and and Farooq, 2010). South Asia and Sub-Saharan Africa constitute most of the world's hungry population (Vermeulen, et al., 2011); the most vulnerable region to climate change is South Asia (Bandara and Cai, 2014). In South Asia, more than 70\% of the people (approximately 1.1 billion) live in rural regions dominated by agriculture, and almost $75 \%$ of these people are poor (World Bank, 2012). Earlier studies indicate that the rising temperature also diminishes the rice yield (M. Ahmad, et al., 2013). It is estimated that a 6 percent decline in rainfall can mount the country's net irrigation water requirements by 29 percent. This rise in temperature and decrease in rainfall may not only affect the crops production mainly cereals, fruits and vegetables but also about 1.3 million small farms. Therefore, the study intends to measure the effects of climate (temperature, rainfall) and technological progress (fertilizer use and agricultural machinery) on the major crops (wheat, rice, and maize) of Pakistan. This study differs certainly from the previous investigations on the topic as the technological progress aspect was overlooked by most of the studies, that may mitigate the climate change effect.

Keeping in view its significance the dilemma has received much attention amongst the contemporary researchers. A myriad of research scholars including (Acaravci and Ozturk, 2010; Janjua, et al., 2014; Arshed and Abduqayumov, 2016; Asumadu-Sarkodie and Owusu, 2016) have employed Autoregressive Distributed Lag (ARDL) technique to identify the relationship between climatic variation and various related factors on agriculture. Because ARDL model aids to determine the long-run relationships among several variables (Pesaran, et al., 2001). The main feature of this model is to find out the long-run or short-run interrelation between variables. ARDL model can be employed even for the smaller data and order of variable integration is not required. Owing to its superiority over other techniques the present study also exploits ARDL model to detect the impact of weather and technological progress variables over the yields of main food crops.

The study is organized into sections. The introduction is followed by materials and methods section which includes data sources, Estimation Technique and model specification. The third section describes the results and discussions and the fourth final section concludes the study.

\section{MATERIALS AND METHODS}

Data: The aim of this research work is to measure the effects of climate (temperature, rainfall) and technological progress (fertilizer use and agricultural machinery) on the major crops (wheat, rice, and maize) of Pakistan. Time series data (1989 to 2015) are employed on the above parameters. Data on crop yield are collected from various issues of the Agricultural Statistics of Pakistan. While the data on climate variables are gathered from Pakistan Meteorological Department. Data on climatic variables are segregated according to the respective district and cropping season commencing from sowing to harvesting time. Data on fertilizer application and use of agricultural machinery are gathered from various issues of the Economic Survey of Pakistan.

Estimation Technique: The issue of spurious regression is common to time series data. Tackling the issue of spurious regression and to examine the long-run relationship among time-series variables cointegration test is employed (Nkoro, 2016). Therefore, the Autoregressive Distributed Lag (ARDL) model suggested by (Pesaran, et al., 2001) is selected and incorporated in this study due to its superiority over other techniques. For example (a) in case of small sample size ARDL model is best to exploit, (b) regardless of the similar combination of integration of the study variables, yet ARDL model can effectively be applied ${ }^{1}$ (c) to analyze short-run and

\footnotetext{
${ }^{1}$ As a consequence, ARDL is suitable regardless of the model and the variables are absolutely $I(0)$ (which shows that the variables were stationary in their level form and were integrated at order zero) or I(1) (which indicates that the variables were integrated at first order and stationary in their differences and)
} 
long-run coefficients at same time, ARDL can be used. Notably, the ARDL procedure comprises of the biascorrected bootstrap technique and non-linear process of the coefficients of the conditional error correction model. Furthermore, the ARDL can be applied for the estimation of steady numerical inferences for a long-run relationship between the study variables.

The Model: The following model is developed and estimated to get the correlation among the yield of selected crops (wheat, rice and maize), climate (temperature and rainfall) and technological (fertilizer and agricultural machinery) growth aspects;

$Y_{t}=f\left(A_{t}, T_{t}, R_{t}, F_{t}, M_{t}\right)$

Where $Y_{t}$ is yield (in kilogram per acre) of the respective crop (wheat, rice and maize), $A_{t}$ is area (thousand hectares) under the respective crop, $T$ is temperature (in degree Celsius), $R$ is total rainfall (in millimeters), $F$ is the fertilizer used (millions tons) and $M$ is agricultural machinery used (units of ten thousand kilowatts) while ${ }^{t}$ represents the time period (year).

Equation 1 in $\log$ form is presented below

$\ln Y_{t}=\alpha_{0}+\alpha_{1} \ln A_{t}+\alpha_{2} \ln T_{t}+\alpha_{3} \ln R_{t}+\alpha_{4} \ln F_{t}+\alpha_{5} \ln M_{t}+\varepsilon t$

As the study focuses on the long-run and short-run relationships among variables while the ARDL model does not take account of the year term. Hence, the ARDL model is formulated as:

$\ln Y_{t}=\beta_{0}+\beta_{1} \ln Y_{t-i}+\beta_{2} \ln Y A_{t-i}+\beta_{3} \ln T_{t-i}+\beta_{4} \ln K_{t-i}+\beta_{5} \ln F_{t-i}^{i}+\beta_{6} \ln M_{t-i}+\varepsilon_{t}$

To evaluate the long-run relationship among variables, the Error Correction Model (ECM) can be established. Equation 3 in general ECM equation is given below:

$\ln \Delta Y_{\mathrm{t}}=\lambda_{0}+\lambda_{1 i} \sum_{i=1}^{\mathrm{p}} \Delta \ln Y_{\mathrm{t}-\mathrm{i}}+\lambda_{2 j} \sum_{j=1}^{\mathrm{q}} \Delta \ln A_{t-i}+\lambda_{3 k} \sum_{k=1}^{\mathrm{q}} \Delta \ln T_{\mathrm{t}-\mathrm{i}}+\lambda_{4 l} \sum_{l=1}^{\mathrm{q}} \Delta \ln R_{\mathrm{t}-\mathrm{i}}+$
$\lambda_{5 m} \sum_{m=1}^{\mathrm{q}} \Delta \ln F_{t-i}+\lambda_{6 n} \sum_{n=1}^{\mathrm{q}} \Delta \ln M_{t-i}+\varphi E C M_{t-i}+\varepsilon_{t}$

Where, $\lambda_{0}$ is a drift component, $\Delta$ is the firstdifference operator and $\varepsilon_{t}$ is a white noise term. Error correction dynamics used in equation 4 are the terms with summation signs. The coefficient $\lambda_{1 i}, \lambda_{2 j}, \lambda_{3 k}, \lambda_{41}, \lambda_{5 m}, \lambda_{6 r}$ indicates the short-run dynamics of the model while the $\beta_{1}, \beta_{2}, \beta_{3}, \beta_{4}, \beta_{5}, \beta_{6}$ are long-run coefficient and

or mutually co-integrated. The integration order, denoted as $I(d)$, is a statistic outline for a time series that accounts for the least possible number of differences prescribed to acquire a covariance stationary series (Hansen, 1995). represents the long-run relationship among the study variables.

\section{RESULTS AND DISCUSSION}

Descriptive Statistics: To understand the fundamental properties of all the variables under the study a descriptive statistics of the variables are derived and reported in Table 1. During wheat, rice and maize crops growing seasons, the minimum average temperature was $16.2^{\circ} \mathrm{C}, 29.2^{\circ} \mathrm{C}$ and $22.3^{\circ} \mathrm{C}$ while the maximum average temperature was $18.7^{\circ} \mathrm{C}, \quad 31.2^{\circ} \mathrm{C}$ and $26.1^{\circ} \mathrm{C}$, respectively. Table 1 , shows large variations in wheat and rice yield per unit area but maize increases more with respect to wheat and rice crops from 1989 to 2015 . For example, the minimum yield of maize crop is reported as $13644 \mathrm{~kg} / \mathrm{ha}$ while the maximum yield is calculated as $44257 \mathrm{~kg} / \mathrm{h}$. Figure 1 portrays that maize yield sharply increased from 1989 to 2015 $\left(y-1334.1 x+6516.2, R^{2}-0.91\right)$.

During the study period (1989 to 2015) a gradual increase is observed in the average temperature (Figure 2), especially for wheat crops. Total rainfall also indicates fluctuation in the growing periods of all crops (Figure 3). It is projected that the average temperature will increase and patterns of rainfall will change (Ali, et al., 2017). During the summer season, most of the climate models expected that rainfall will increase. Similarly, the inclusion of technological variables i.e., total fertilizer (Figure 4) and agricultural machinery (Figure 5) risen from 1989 to 2015. In 2015 the maximum value of agricultural machinery was 23884 $10^{4} \mathrm{kw}$, while the minimum value was $1399410^{4} \mathrm{kw}$ in 1989 for all crops.

To examine the normality of all variables Jarque-Bera (J-B) test is adopted. The test shows that the residuals for all the variables are normal as the $\mathrm{J}$-B values for all the variables are highly insignificant at 5 percent significance level.

Unit Root Test: The unit root test is applied to find out the stationarity of the data. In case the data is not stationary then the obtained results may become meaningless, unreliable and unverifiable. The unit root is tested with the Augmented Dickey-Fuller (ADF) and Phillips Perron (PP) specifications. The result of both the $\mathrm{ADF}$ and $\mathrm{PP}$ for wheat crop shows that variable $\mathrm{Y}$ is stationary at level and at first difference form. While the variables $\mathrm{A}, \mathrm{F}$ and $\mathrm{M}$ are not stationary at level form but stationary at first difference (at 1 percent significance level). Whereas the other two variables $\mathrm{T}$ and $\mathrm{R}$ are stationary in level form (at 10 percent significance level) and at first differences (at the 1 percent significance level). For rice crops, the variables $\mathrm{Y}, \mathrm{F}$ and $\mathrm{M}$ are not stationary at level form but stationary at first difference (at 1 percent level of significance). Variable $\mathrm{T}$ is 
stationary at level and at first difference form. The two other variables, A is stationary at both the levels and at first difference form in ADF, while in PP it is stationary in the level form (at 5 percent level of significance) and also stationary at first difference (at 1 percent significance level). While $\mathrm{R}$ is not stationary at level form and becomes stationary at first difference in ADF test, and $\mathrm{PP}$ test reveals that $\mathrm{R}$ is stationary at level form (at 5 percent level of significance) and also stationary at first difference (at 1 percent significance level). Similarly, the results of maize crop are also depicted in Table 2.
Lag Order: It is important to find out how many lags to be used in ARDL model. Therefore, to figure out the optimal number of lags for the model, the unrestricted Vector Autoregression (VAR) lag selection criteria is tested. Table 3 formulates the lag selection criteria for the model but most commonly employed criteria are Akaike Information Criterion (AIC) and Schwarz Information Criterion (SIC). The AIC reveals that the suitable lag value is lag 2 for wheat and rice crop in the model while for maize crop the best-chosen lag is 1 .

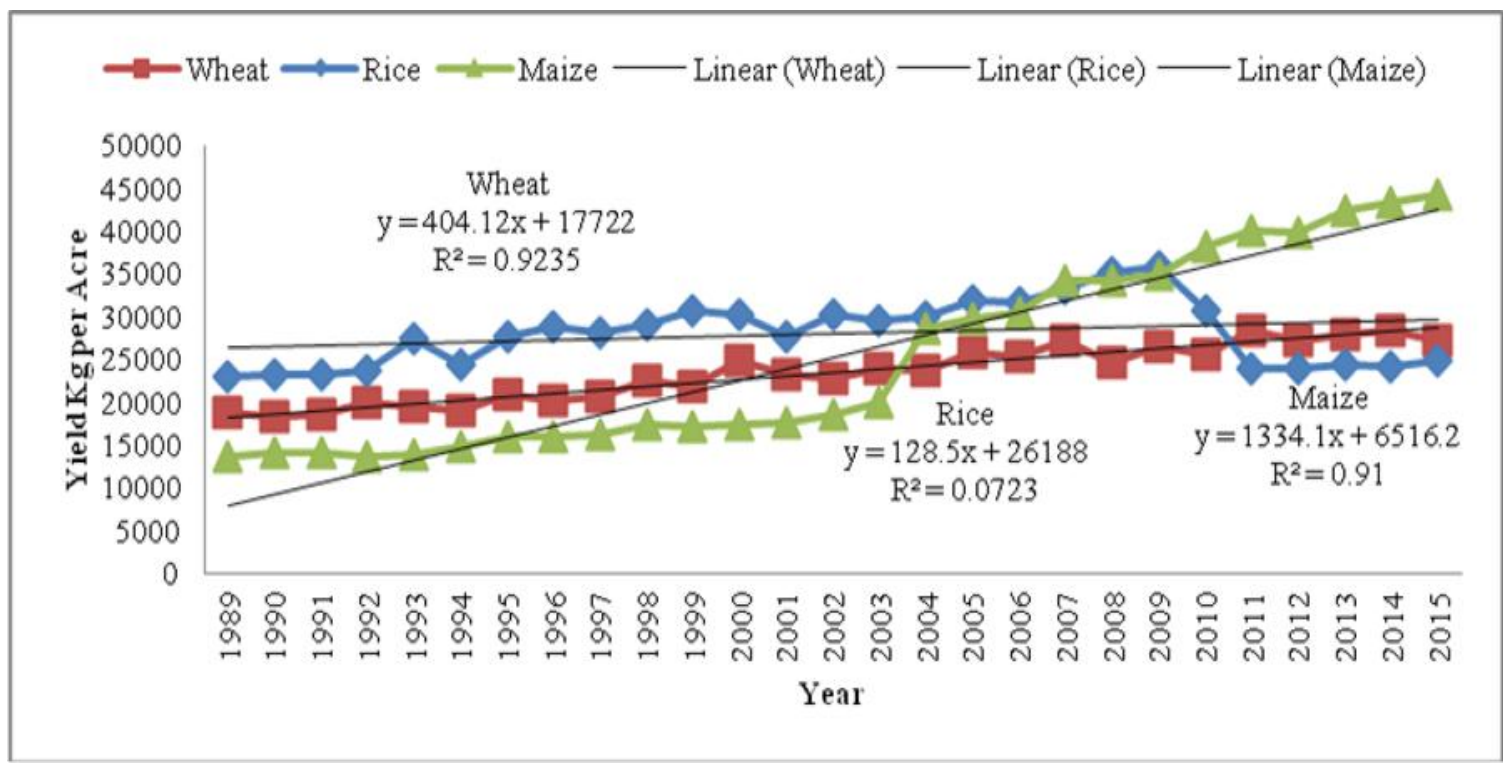

Figure 1. Per Acre yield of major crops.

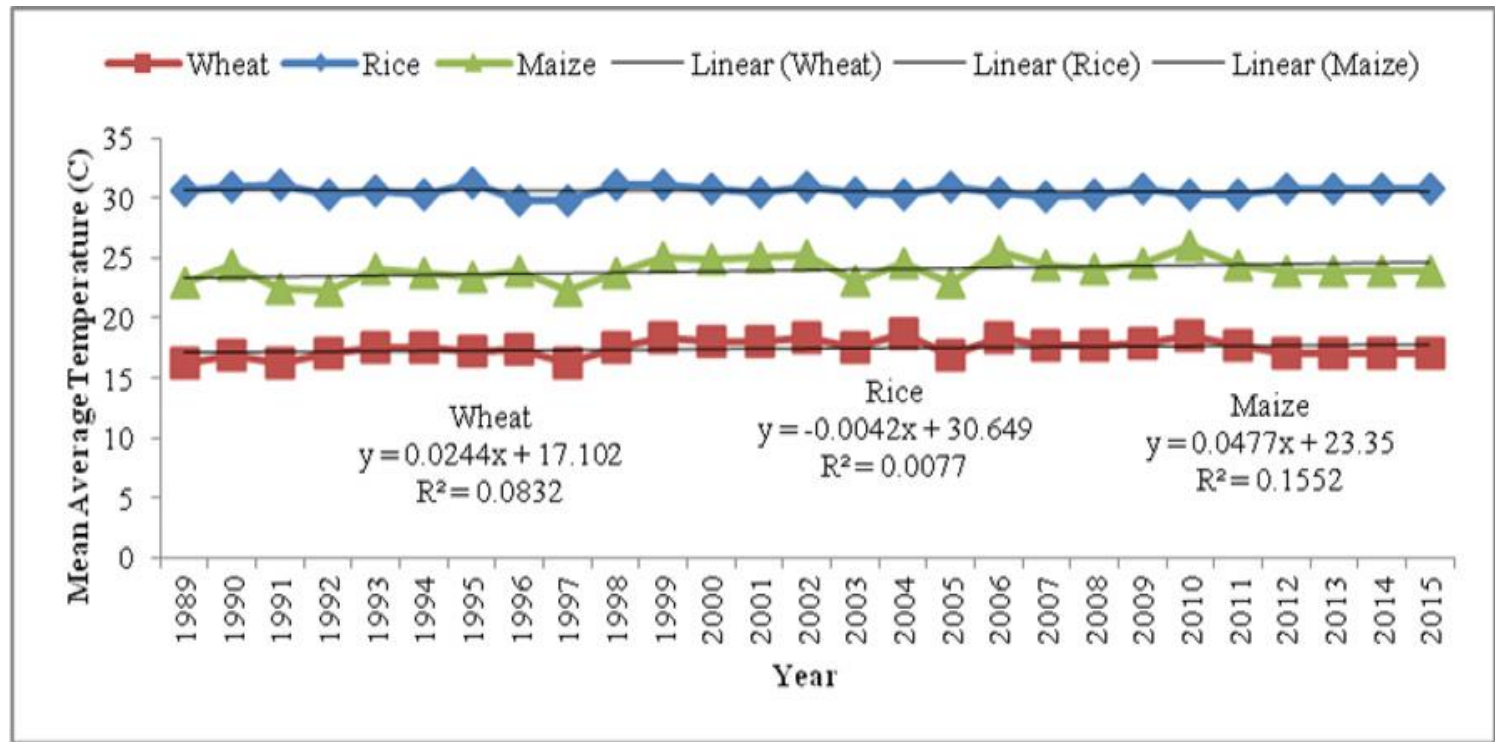

Figure 2. Average annual temperature for major crops. 


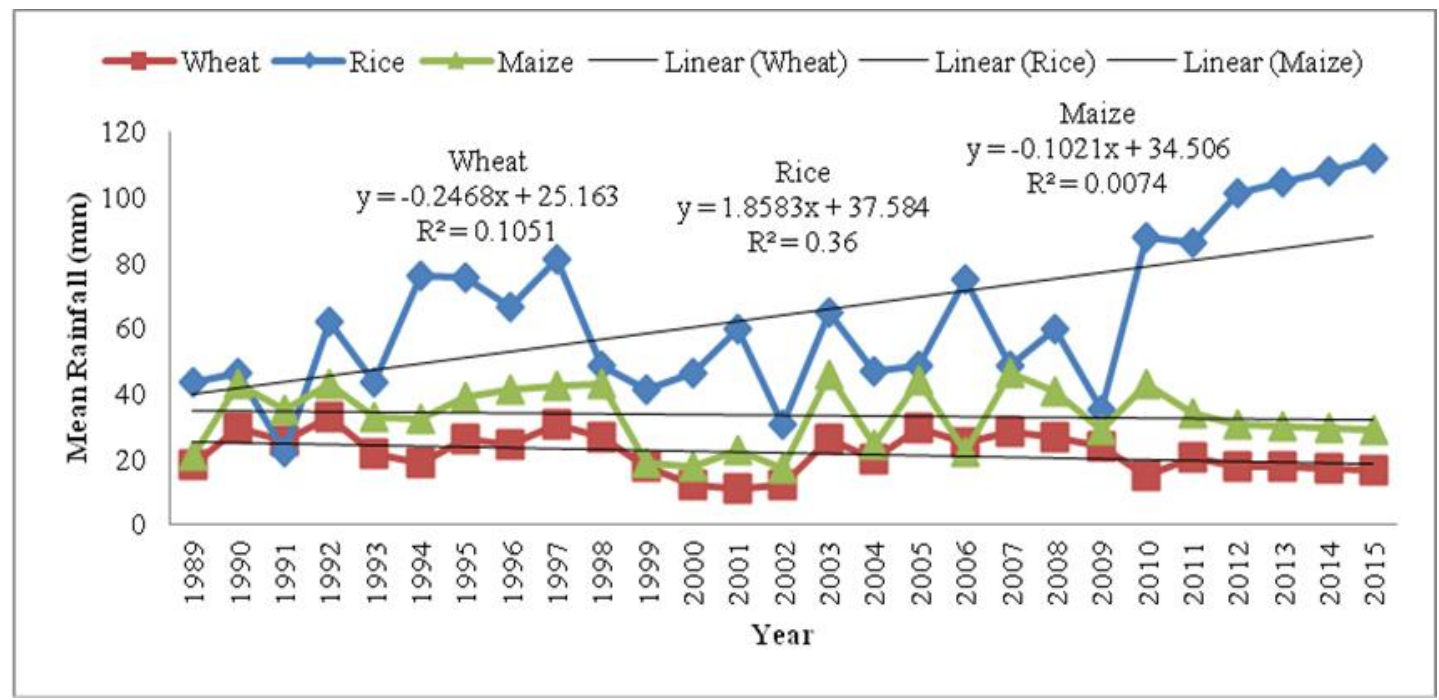

Figure 3. Average annual rainfall for major crops.

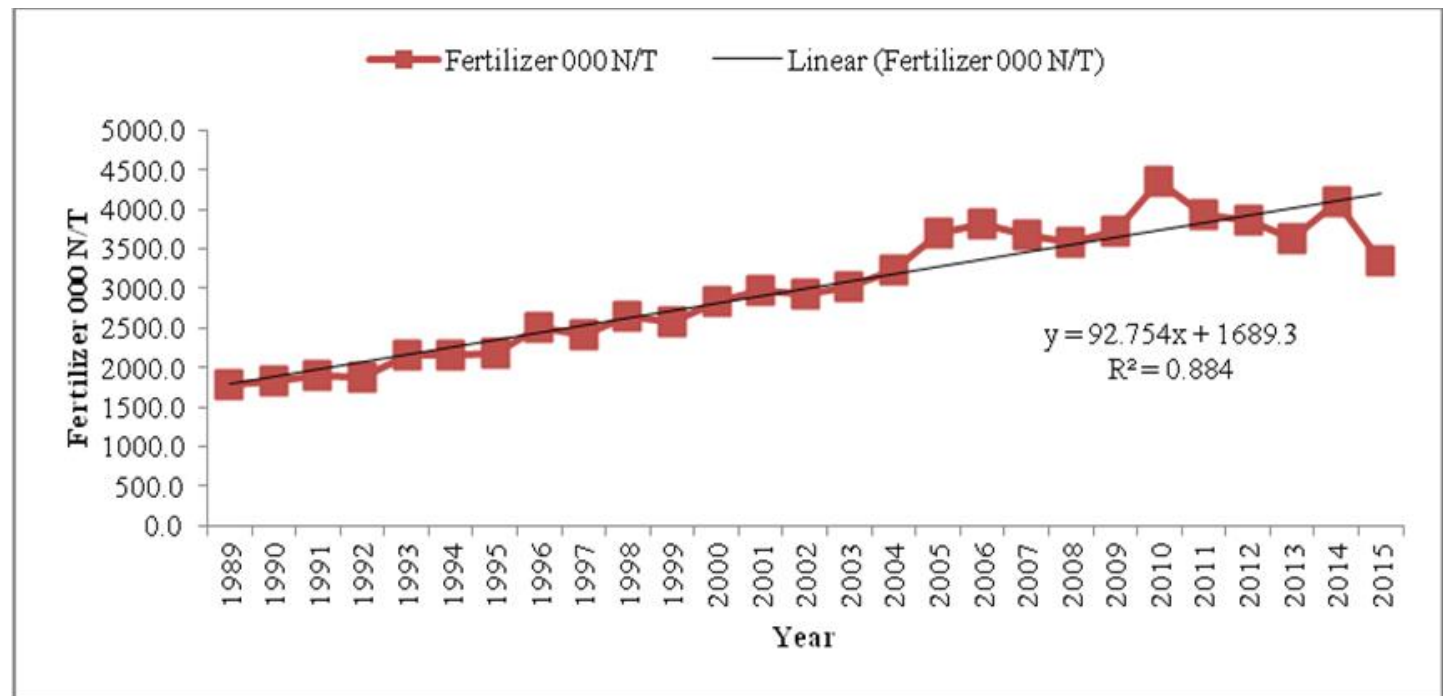

Figure 4. Average annual fertilizer used in $000 \mathrm{~N} / \mathrm{T}$.

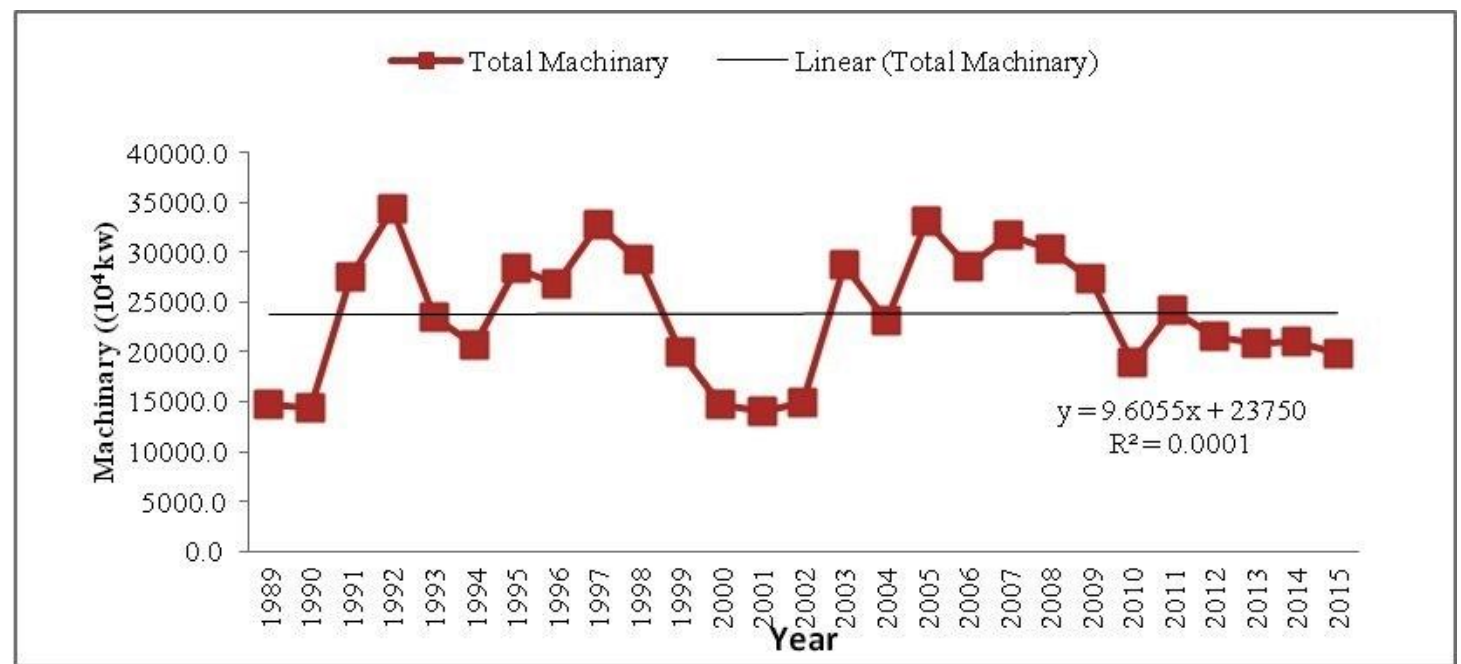

Figure 5. Total power of agricultural machinery $\left(10^{4} \mathrm{kw}\right)$. 
Table 1. Descriptive statistics.

\begin{tabular}{|c|c|c|c|c|c|}
\hline Crops & Variables & Mean & Max. & Min. & S.D \\
\hline \multirow{6}{*}{ Maize } & Yield (Kg/ha) & 25193 & 44257 & 13644 & 11100 \\
\hline & Area (hectare) & 977266 & 1191000 & 845200 & 95153 \\
\hline & Mean temperature $\left({ }^{\circ} \mathrm{C}\right)$ & 24 & 26.1 & 22.3 & 1 \\
\hline & Rainfall (mm) & 33.1 & 46.3 & 16.9 & 9.4 \\
\hline & Fertilizer $\left(10^{4} t\right)$ & 2987.9 & 4360 & 1790.2 & 783 \\
\hline & T Machinery $\left(10^{3} \mathrm{kw}\right)$ & 23884 & 34357.1 & 13994 & 6285.7 \\
\hline \multirow{6}{*}{ Rice } & Yield (kg/ha) & 27987 & 35845 & 22925 & 3793 \\
\hline & Area (hectare) & 2414617 & 2962600 & 1973400 & 275904 \\
\hline & Mean temperature $\left({ }^{\circ} \mathrm{C}\right)$ & 30.6 & 31.2 & 29.8 & 0.4 \\
\hline & Rainfall (mm) & 63.6 & 111.7 & 22.1 & 24.6 \\
\hline & Fertilizer $\left(10^{4} t\right)$ & 2987.9 & 4360 & 1790.2 & 783 \\
\hline & T Machinery $\left(10^{3} \mathrm{kw}\right)$ & 23884 & 34357.1 & 13994 & 6285.7 \\
\hline \multirow{6}{*}{ Wheat } & Yield $(\mathrm{kg} / \mathrm{ha})$ & 23380 & 28328 & 18249 & 3338 \\
\hline & Area (hectare) & 8394075 & 9204000 & 7729600 & 421087 \\
\hline & Mean temperature $\left({ }^{\circ} \mathrm{C}\right)$ & 17.4 & 18.7 & 16.2 & 0.7 \\
\hline & Rainfall (mm) & 21.7 & 32.5 & 11 & 6 \\
\hline & Fertilizer $\left(10^{4} t\right)$ & 2987.9 & 4360 & 1790.2 & 783 \\
\hline & T Machinery $\left(10^{3} \mathrm{kw}\right)$ & 23884 & 34357.1 & 13994 & 6285.7 \\
\hline
\end{tabular}

Source: Authors' calculation

Table 2. Unit Root Tests.

\begin{tabular}{|c|c|c|c|c|c|c|c|c|}
\hline Crop & Test & Variables & Yield & Area & Temp & Rain & Fertilizer & Machinery \\
\hline \multirow{4}{*}{ Wheat } & & Level & $-5.43^{* * *}$ & -2.98 & $-3.65^{*}$ & $-3.26^{*}$ & 2.5084 & -2.91 \\
\hline & ADF & $1^{\text {st }}$ Diff & $-10.49^{* * *}$ & $-6.15^{* * *}$ & $-9.06^{* * *}$ & $-6.17^{* * *}$ & $-4.69^{* * *}$ & $-5.27^{* * *}$ \\
\hline & & Level & $-5.45^{* * *}$ & -2.98 & $-3.56^{* *}$ & -3.14 & -0.71 & -2.96 \\
\hline & PP & $1^{\text {st }}$ Diff & $-19.57^{* * *}$ & $-6.57^{* * *}$ & $-18.71^{* * *}$ & $-6.17^{* * *}$ & $-7.67^{* * *}$ & $-5.26^{* * *}$ \\
\hline \multirow{4}{*}{ Rice } & & Level & -1.45 & $-4.79^{* * *}$ & $-4.60^{* * *}$ & -1.94 & 2.51 & -2.91 \\
\hline & ADF & $1^{\text {st }}$ Diff & $-4.89^{* * *}$ & $-6.05^{* * *}$ & $-6.77^{* * *}$ & $-9.97^{* * *}$ & $-4.69^{* * *}$ & $-5.27^{* * *}$ \\
\hline & & Level & -1.49 & $-3.84^{* *}$ & $-5.20^{* * *}$ & $-4.21^{* *}$ & -0.71 & -2.96 \\
\hline & PP & $1^{\text {st }}$ Diff & $-4.91^{* * *}$ & $-11.28^{* * *}$ & $-14.37^{* * *}$ & $-10.56^{* * *}$ & $-7.67^{* * *}$ & $-5.26^{* * *}$ \\
\hline \multirow{4}{*}{ Maize } & & Level & -2.12 & -2.99 & $-4.60^{* * *}$ & $-4.79^{* * *}$ & 2.51 & -2.91 \\
\hline & ADF & $1^{\text {st }}$ Diff & $-4.36^{* * *}$ & $-6.12^{* * *}$ & $-8.11^{* * *}$ & $-10.05^{* * *}$ & $-4.69^{* * *}$ & $-5.27^{* * *}$ \\
\hline & & Level & -2.12 & -2.99 & $-4.60^{* * *}$ & $-4.84^{* * *}$ & -0.71 & -2.96 \\
\hline & PP & $1^{\text {st }}$ Diff & $-4.34^{* * *}$ & $-6.65^{* * *}$ & $-12.85^{* * *}$ & $-10.05^{* * *}$ & $-7.67^{* * *}$ & $-5.26^{* * *}$ \\
\hline
\end{tabular}

${ }^{* * * * *}$, and ${ }^{*}$ represent significance level at $1 \%, 5 \%$, and $10 \%$, respectively

Source:Authors' calculation 
Table 3. VAR Lag Order Selection Criteria.

\begin{tabular}{cllccccc}
\hline Crops & Lag & LogL & LR & FPE & AIC & SC & HQ \\
\hline \multirow{3}{*}{ Wheat } & 0 & 225.880 & NA & 0.000 & -17.590 & -17.298 & -17.509 \\
& 1 & 309.880 & 120.960 & 0.000 & -21.430 & -19.383 & -20.862 \\
& 2 & 378.697 & $66.065^{*}$ & $2.83 \mathrm{e}-18^{*}$ & $-24.056^{*}$ & $-20.253^{*}$ & $-23.001^{*}$ \\
\hline \multirow{3}{*}{ Rice } & 0 & 123.460 & NA & 0.000 & -9.397 & -9.104 & -9.316 \\
& 1 & 186.688 & $91.049^{*}$ & 0.000 & -11.575 & $-9.527^{*}$ & -11.007 \\
& 2 & 235.195 & 46.566 & $2.74 \mathrm{e}-13^{*}$ & $-12.576^{*}$ & -8.773 & $-11.521^{*}$ \\
\hline \multirow{3}{*}{ Maize } & 0 & 118.011 & NA & 0.000 & -8.961 & -8.668 & -8.880 \\
& 1 & 202.432 & $121.566^{*}$ & $1.18 \mathrm{e}-13^{*}$ & $-12.835^{*}$ & $-10.787^{*}$ & $-12.267^{*}$ \\
& 2 & 232.889 & 29.238 & 0.000 & -12.391 & -8.588 & -11.336 \\
\hline
\end{tabular}

*Shows lag order selected by the criterion (at 5\% level); Source: Authors' calculation

$\mathrm{LR}=$ sequential modified LR test statistic; FPE = Final Prediction Error; AIC = Akaike Information Criterion; SC $=$ Schwarz Information Criterion; $H Q=$ Hannan-Quinn Information Criterion

Bound Test: This study employes ARDL technique because this method is exploited to investigate the equations when the variables are stationary at different levels (Asumadu-Sarkodie and Owusu, 2016). Before the application of the ARDL model, the existence of cointegration among the variables should be assured to be employed. To find out the existence of cointegration among the variables in short-run and long-run relationships, the ARDL bound test is employed. The results for wheat crop disclose that the F-statistics value 6.77 (Table 4) is higher than the upper bound value at 5 percent significance level so it is most effective and appropriate to employ the ARDL model. Likewise, for rice crops, the F-statistics value is 3.44 which is in between the lower and upper bound value and significant at 5 percent level of significance. For maize crop, the Fstatistics value is 7.06 which is above the upper bound value and significant at 5 percent level of significance. Therefore, the null hypothesis of no cointegration among the variables is rejected. All these ARDL results do indicate that there exists a long-run association between the variables when the chosen crops (wheat, rice and maize) yield per unit area is taken as a dependent variable.

Table 4. ARDL Bound Test for Cointegration.

\begin{tabular}{|c|c|c|c|c|c|c|}
\hline \multirow{2}{*}{ Crop } & \multirow{2}{*}{ Model } & \multirow{2}{*}{ F-Value } & \multirow{2}{*}{$\begin{array}{c}\text { Critical Value } \\
(\%)\end{array}$} & \multicolumn{2}{|c|}{ Bound value } & \multirow{2}{*}{ Conclusion } \\
\hline & & & & Lower & Upper & \\
\hline \multirow{4}{*}{ Wheat } & \multirow{4}{*}{$\operatorname{ARDL}(1,1,0,1,1,1) \mathrm{k}(5)$} & \multirow{4}{*}{6.77} & 10 & 2.26 & 3.35 & \multirow{4}{*}{ Cointegration } \\
\hline & & & 5 & 2.62 & 3.79 & \\
\hline & & & 2.5 & 2.96 & 4.18 & \\
\hline & & & 1 & 3.41 & 4.68 & \\
\hline \multirow{4}{*}{ Rice } & \multirow{4}{*}{$\operatorname{ARDL}(1,2,3,3,3,2) \mathrm{k}(5)$} & \multirow{4}{*}{3.44} & 10 & 2.26 & 3.35 & \multirow{4}{*}{ Cointegration } \\
\hline & & & 5 & 2.62 & 3.79 & \\
\hline & & & 2.5 & 2.96 & 4.18 & \\
\hline & & & 1 & 3.41 & 4.68 & \\
\hline \multirow{4}{*}{ Maize } & \multirow{4}{*}{$\operatorname{ARD} L(5,2,2,2,2,2) \mathrm{k}(5)$} & \multirow{4}{*}{7.06} & 10 & 2.26 & 3.35 & \multirow{4}{*}{ Cointegration } \\
\hline & & & 5 & 2.62 & 3.79 & \\
\hline & & & 2.5 & 2.96 & 4.18 & \\
\hline & & & 1 & 3.41 & 4.68 & \\
\hline
\end{tabular}

Source: Authors' calculation

Short-Run Estimates: Based on the ARDL bounds test approach, the empirical findings demonstrate that there is a short-run relationship among the variables. For wheat crop, the coefficient of cultivation area is positive and statistically significant at 1 percent level. This endorses that in the short-run, a rise in the wheat crop growing area will perform an essential role in the improvement in wheat yield per unit area in Pakistan. The results estimate that a 1 percent increase in the wheat cultivation area can lead to a rise in the wheat yield per unit area by $1.69 \%$ (Table 5). In the short-run, the temperature has a negative and significant effect on the wheat yield which means that a 1 percent rise in temperature will lead to a 1.02 percent decrease in wheat yield. Moreover, a $1 \%$ rise in the rainfall and fertilizer will cause a 1.06 percent and 0.21 percent decrease in wheat yield, respectively. 
The short-run findings can also demonstrate that there is Error Correction Term (ECT) which depicts the cointegration association among the variables. The coefficient of ECT(-1) for wheat crop is negative and statistically significant at 1 percent level, which indicates that approximately 1.8 percent disequilibria from the shock converge of the previous year to the long-run equilibrium in the current year. Some previous studies show that the coefficient of ECT(-1) value lies between 0.01 and -1.99 (Narayan and Smyth, 2006; Samargandi, et al., 2014). The coefficient of ECT(-1) value for rice and maize crops are -0.32 and -0.14 , respectively.

Long-Run Estimates: Table 4 illustrates the outcomes from the estimation of ARDL bound test, which reveals that cointegration exists among the variables. So the long-run and short-run relationships can be projected between the selected crop yield, climatic change factors and technical progress. The outcomes of the long-run coefficient are portrayed in Table 6 , which reveals that area and temperature are negative and statistically significant. This turns in a 1 percent increase in area and temperature will lead to 0.51 percent and 0.56 percent decrease in wheat yield, respectively. The estimates also indicate that rainfall has a negative effect yet statistically insignificant. The long-run coefficient of fertilizer use is positive and significant, which reveals that a 1 percent increase in the usage of fertilizer will lead to 0.46 percent increase in the wheat yield. Furthermore, the agricultural machinery coefficient is positive and insignificant. Similarly, the same estimations are used for both rice and maize crops. Area, temperature, fertilizer use and machinery coefficient are statistically insignificant while rainfall coefficient is negative and statistically significant. For maize crops, none of the variables are statistically significant.

Table 5. Short-Run ARDL model.

\begin{tabular}{lccccccc}
\hline Variable & $D(\ln Y(-1))$ & $D(\ln A)$ & $D(\ln M T)$ & $D(\ln R)$ & $D(\ln F)$ & $D(\ln M)$ & $E C T(-1)$ \\
\hline \multirow{2}{*}{ Wheat } & 0.49 & $1.70^{* * *}$ & $-1.02^{* *}$ & -1.06 & -0.22 & 1.07 & $-1.81^{* * *}$ \\
& $(0.28)$ & $(0.47)$ & $(0.40)$ & $(0.74)$ & $(0.19)$ & $(0.84)$ & $(0.4)$ \\
\hline \multirow{2}{*}{ Rice } & 0.19 & 1.04 & $-0.09^{*}$ & -0.02 & 0.02 & $-0.33^{*}$ \\
& $(0.21)$ & $(1.47)$ & $(0.05)$ & $(0.11)$ & $(0.06)$ & $(0.16)$ \\
\hline \multirow{2}{*}{ Maize } & 0.54 & 0.16 & 0.001 & 0.24 & 0.01 & -0.14 \\
Cointegration & $(0.39)$ & $(0.66)$ & $(0.07)$ & $(0.16)$ & $(0.08)$ & $(0.12)$ \\
\hline Wheat $\ln Y-\left(-0.52^{*} \ln A-0.56^{*} \ln M T-0.65^{*} \ln R+0.47^{*} \ln F+0.65^{*} \ln M+11.64\right)$ \\
Rice & $\ln Y-\left(0.59^{*} \ln A+3.19^{*} \ln M T-0.28^{*} \ln R-0.05^{*} \ln F+0.42^{*} \ln M-11.94\right)$ \\
Maize $\ln Y-\left(0.06^{*} \ln A+1.11^{*} \ln M T+0.01^{*} \ln R+1.68^{*} \ln F+0.09^{*} \ln M-8.49\right)$ \\
\hline
\end{tabular}

Figures in parenthesis are standard errors

Source: Authors' calculation

Table 6. Long-Run ARDL model.

\begin{tabular}{lcccccc}
\hline Variable & $\ln A$ & $\ln T$ & $\ln R$ & $\ln F$ & $\ln M$ & $C$ \\
\hline \multirow{2}{*}{ Wheat } & $-0.52^{* *}$ & $-0.57^{* * *}$ & -0.65 & $0.47^{* * *}$ & 0.65 & $11.64^{* * *}$ \\
& $(0.23)$ & $(0.17)$ & $(0.41)$ & $(0.06)$ & $(0.48)$ & $(4.06)$ \\
\hline \multirow{2}{*}{ Rice } & 0.59 & 3.18 & $-0.28^{* *}$ & -0.05 & 0.42 & -11.94 \\
& $(0.69)$ & $(5.43)$ & $(0.13)$ & $(0.33)$ & $(0.28)$ & $(22.13)$ \\
\hline \multirow{2}{*}{ Maize } & 0.06 & 1.11 & 0.01 & 1.68 & 0.09 & -8.49 \\
& $(3.17)$ & $(4.71)$ & $(0.50)$ & $(1.18)$ & $(0.59)$ & $(42.46)$ \\
\hline
\end{tabular}

Figures in parenthesis are standard errors

Source: Authors' calculation

Diagnostic Tests and Normality plots: Once the cointegration relationship is confirmed for different variables, the cumulative sum (CUSUM) and the cumulative sum of the square of the recursive residuals (CUSUMQ) were implemented to run the ARDL model in a befitting manner. As suggested by (Brown RL, Durbin J, 1975), the CUSUM and CUSUMQ tests are employed based upon the recursive regression residuals. This test indicates, should the statistical line falls inside the critical bounds at a 5 percent significance level. These tests endorse the stability of the coefficients of ARDL model. Figure 7 reveals the wheat, rice and maize crops statistics lie within the 5 percent critical lines, so it reveals that the model coefficients are stable and the 
ARDL model can be employed without a doubt. Figure 6 plots the Cumulative Sum of the Recursive Residuals (CUSUM) and Cumulative Sum of Squares of the Recursive Residuals (CUSUMQ) for all three crops (Wheat, Rice and Maize). The two straight lines (red color) show the critical bounds at the 5 percent significant level. The lines (blue color) in the middle represent the measurements for the cumulative sum of the

\section{CUSUM}
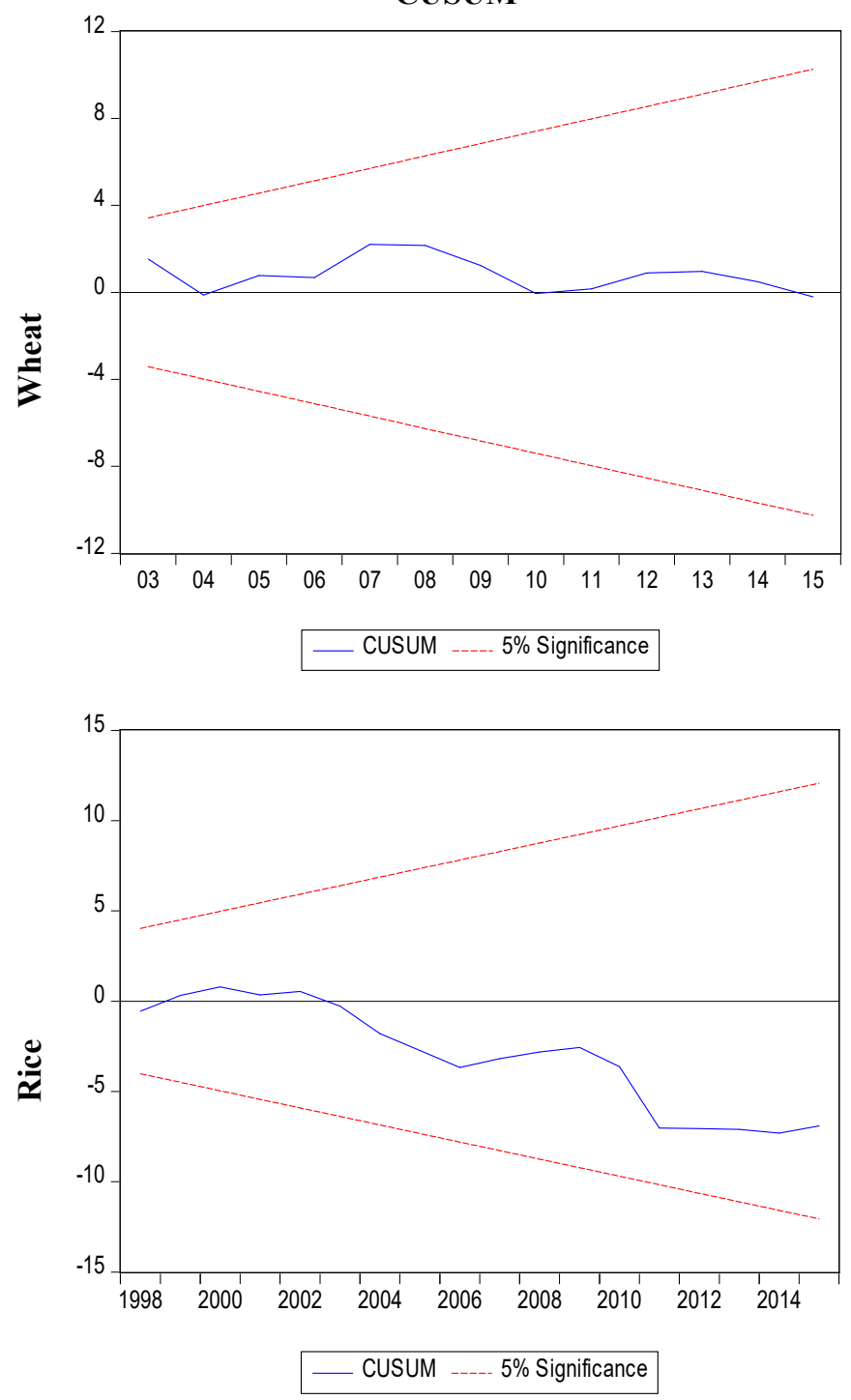

recursive residuals and the cumulative sum of the squares of the recursive residuals. Furthermore, some other diagnostics tests including Serial Correlation, Heteroskedasticity (Table 7) and Normality (Figure 7) test are also applied for testing the good fit of ARDL model. These tests also confirm the inclusion of selected variables in the model.
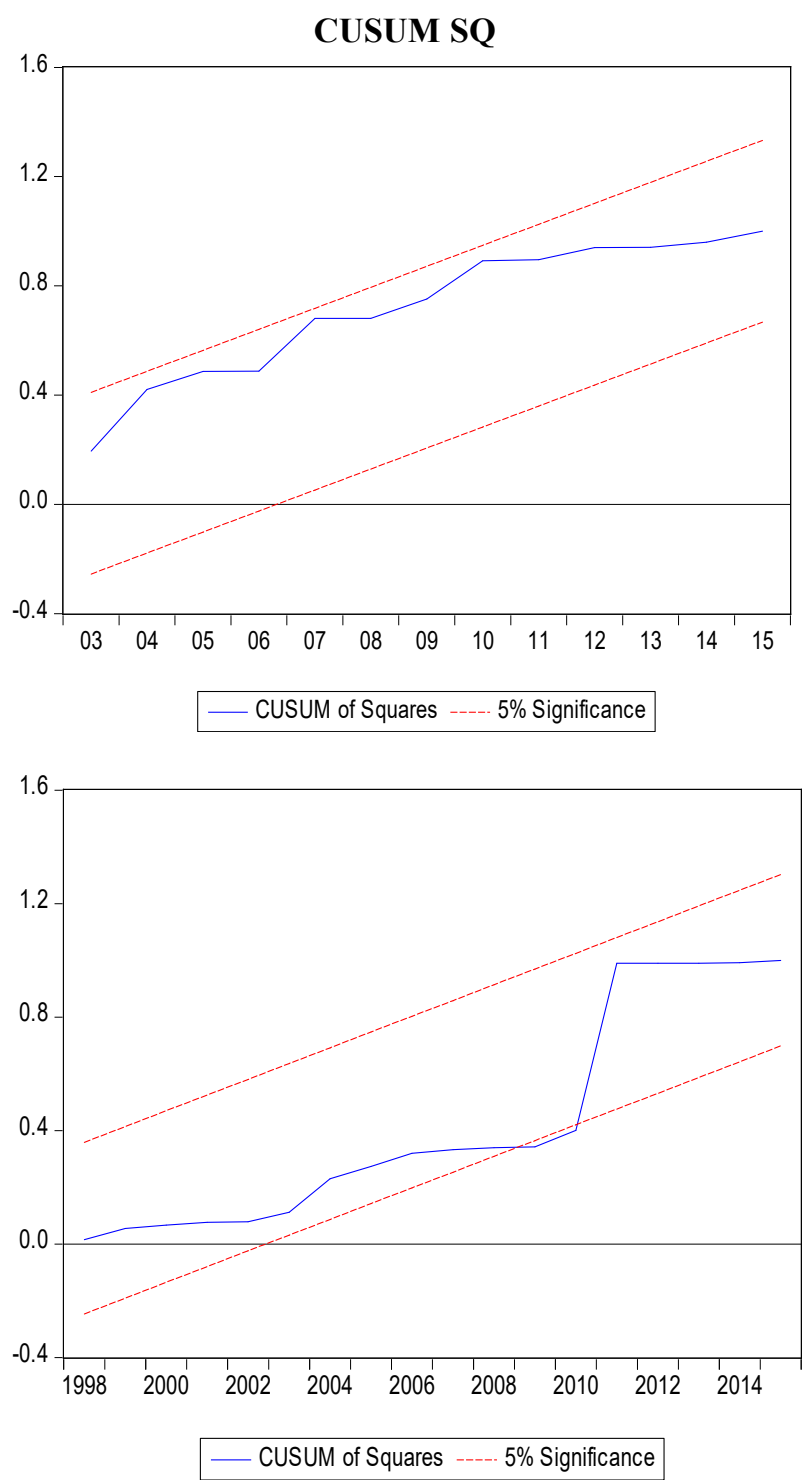

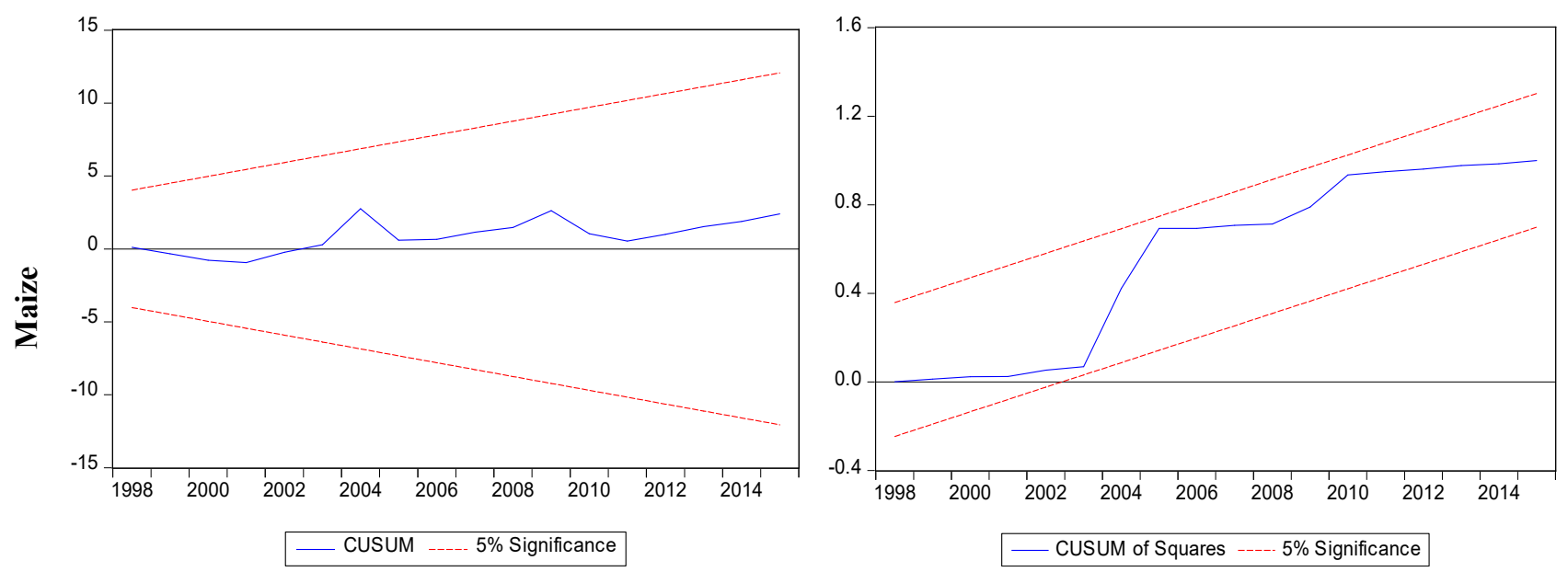

Figure 6. Cumulative Sum of the Recursive Residuals (CUSUM) and Cumulative Sum of Squares of the Recursive Residuals (CUSUMQ).

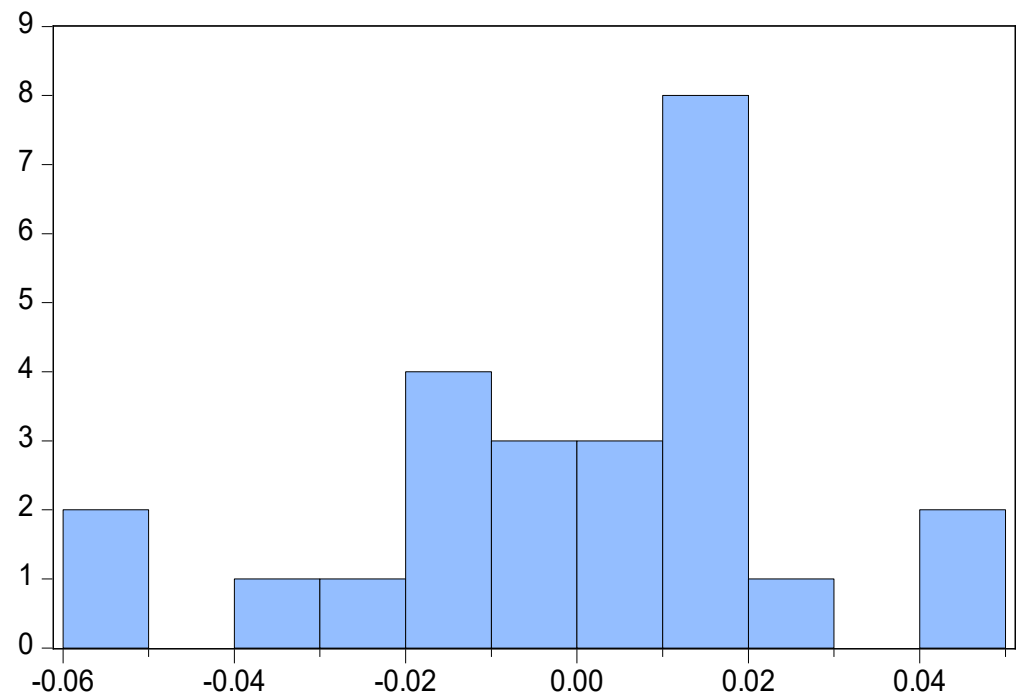

\begin{tabular}{ll}
\hline Series: Residuals \\
Sample 1989 2015 \\
Observations 27 \\
Mean & $-6.25 \mathrm{e}-15$ \\
Median & 0.005518 \\
Maximum & 0.042864 \\
Minimum & -0.053992 \\
Std. Dev. & 0.024712 \\
Skewness & -0.522442 \\
Kurtosis & 2.890482 \\
& \\
Jarque-Bera & 1.149766 \\
Probability & 0.562771
\end{tabular}

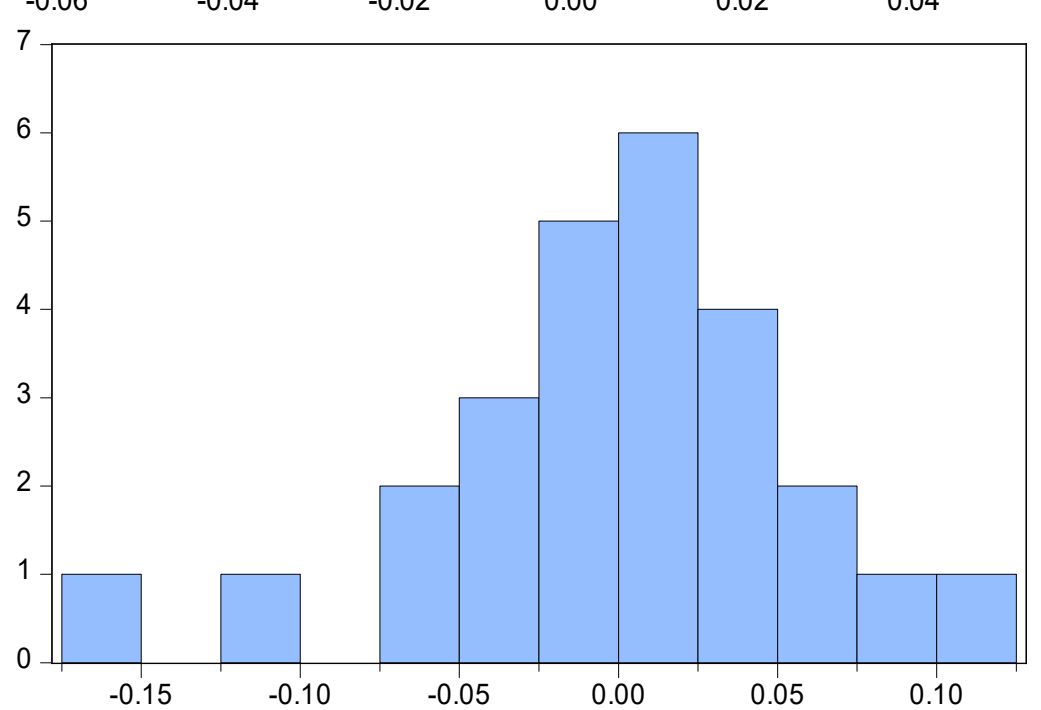

Series: Residuals

Sample 19892015

Observations 27

Mean

$3.74 \mathrm{e}-15$

Median

0.004610

Maximum

0.101490

Minimum $\quad-0.158673$

Std. Dev. $\quad 0.056500$

Skewness $\quad-0.726171$

Kurtosis $\quad 4.033553$

Jarque-Bera $\quad 3.442324$

Probability $\quad 0.178858$

Wheat crop

Rice crop 


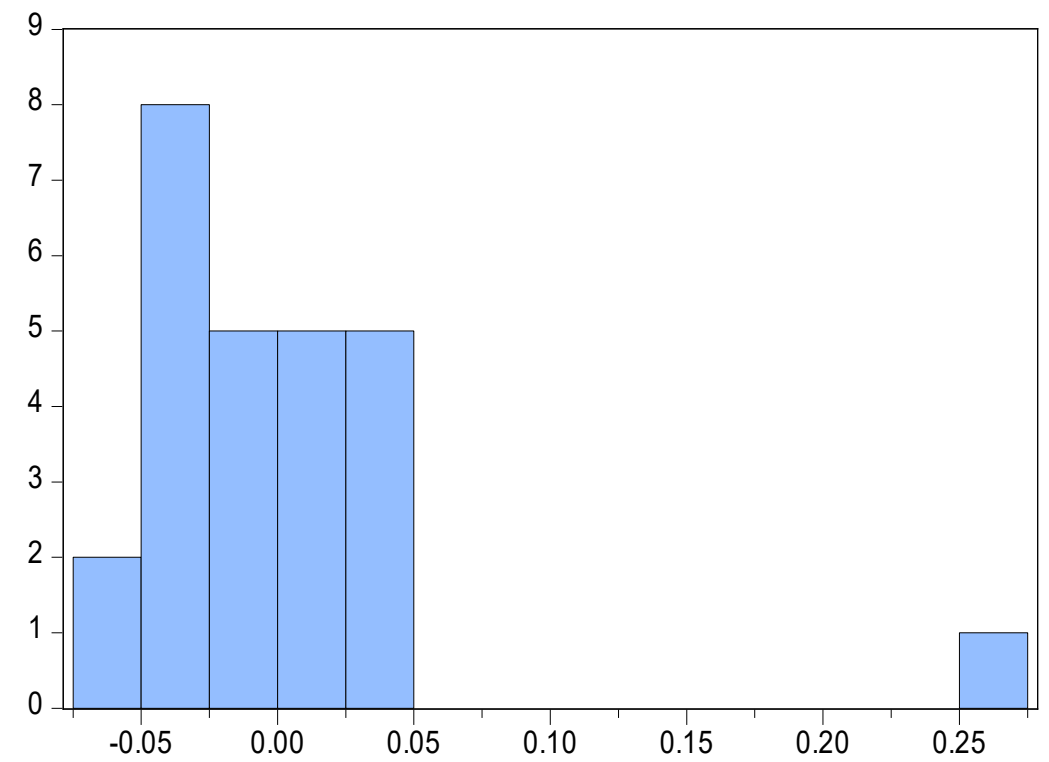

\begin{tabular}{|ll|}
\hline \multicolumn{2}{|l|}{ Series: Residuals } \\
Sample 1989 2015 \\
Observations 27 \\
Mean & $-1.00 \mathrm{e}-16$ \\
Median & -0.014944 \\
Maximum & 0.253565 \\
Minimum & -0.058711 \\
Std. Dev. & 0.061487 \\
Skewness & 2.764033 \\
Kurtosis & 12.20515 \\
& \\
Jarque-Bera & 124.9022 \\
Probability & 0.000000
\end{tabular}

Figure 7. Normality plots for different major food crops

Maize crop

Table 7. Breusch-Pagan-Godfrey Diagnostic Statistic.

\begin{tabular}{lccc}
\hline Test & Wheat & Rice & Maize \\
\hline Serial Correlation Test & & & \\
\hline F-statistic & 0.17 & 0.70 & 0.44 \\
Obs*R-squared & 0.75 & 2.08 & 1.36 \\
Prob. F(2,1) & 0.85 & 0.51 & 0.65 \\
Prob. $\chi^{2}(2)$ & 0.69 & 0.35 & 0.51 \\
\hline Heteroskedasticity Test & & & 0.45 \\
\hline F-statistic & 1.95 & 0.76 & 3.91 \\
Obs*R-squared & 15.56 & 5.95 & 10.50 \\
Scaled explained SS & 3.98 & 4.33 & 0.85 \\
Prob. F(11,13) & 0.13 & 0.62 & 0.79 \\
Prob. $\chi^{2}(11)$ & 0.16 & 0.55 & 0.16 \\
Prob. $\chi^{2}(11)$ & 0.97 & 0.74 & \\
\hline Sour
\end{tabular}

Source: Authors' calculation

Conclusion and policy implication: The findings of the study show the effects of climatic variation and technical progress on the yield of major food crops. As a result, the present study analyzes the relationships among the yield of major food crops (wheat, rice and maize), an area under cultivation of the selected crops, mean temperature, total amount of fertilizer used, rainfall and machinery exploited in Pakistan from 1989 to 2015. ARDL model is employed to measure the effect of climatic variation and other technical factors on the yield of selected crops. The results of the study indicate that few climatic variables affect the crops yield significantly negative, while some variables are significant. The results of the long-run relationship depict that, area and temperature significantly negatively and fertilizer application significantly negatively affect the yield. While the coefficients of rainfall and machinery insignificant.
In conclusion, our study findings suggest that the government of Pakistan can play a vital role by monitoring climatic change and its predicted impact on the agriculture sector and subsequently propagate monitoring results in addition to adaptation practices of farmers at field level. Similarly, according to the warmer climatic conditions of the Punjab region, new crop varieties along with numerous agriculture practices should be followed. The role of agriculture is very important in ensuring food security and decreasing poverty. Temperature increase can affect agriculture through its effect on cropping seasons, the increase in irrigation, the increase in evapotranspiration, and the increasing effect of heat stress on crops. Due to the increased heat and drought tolerance level of new crops may shoulder in the reduction of potential damages. There is a dire need to develop innovative crop farming methods as well as reevaluate the prevalent cropping 
patterns accordingly. The extension services role is also very important for spreading the updated scientific-based information to the farmers at their respective farms.

Acknowledgments: The authors are thankful to the Chinese Scholarship Council (CSC) for providing financial assistance to carry out this research as part of his Ph.D studies in China. In addition, the authors would also like to extend gratitude to anonymous reviewers for providing helpful suggestions on an earlier draft of this paper.

\section{REFERENCES}

Acaravci, A., and Ozturk, I. (2010). On the relationship between energy consumption, $\mathrm{CO} 2$ emissions and economic growth in Europe. Energy, 35(12),

5412-5420. https://doi.org/10.1016/j.energy.2010.07.009

Ahmad, M., and Farooq, U. (2010). The state of food security in Pakistan: Future challenges and coping strategies. The Pakistan Development Review, 903-923.

Ahmad, M., Iqbal, M., and Khan, M. (2013). Climate change, agriculture and food security in Pakistan: adaptation options and strategies. Pakistan Institute of Development Economics, Islamabad, (Climate Change Brief).

Ahmad, M., Mustafa, G., and Iqbal, M. (2015). Impact of Farm Households' Adaptations to Climate Change on Food Security: Evidence from Different Agro-ecologies of Pakistan (Climate Change Working Papers No. 6). Islamabad.

Alcamo, J., Dronin, N., Endejan, M., Golubev, G., and Kirilenko, A. (2007). A new assessment of climate change impacts on food production shortfalls and water availability in Russia. Global Environmental Change, 17(3-4), 429444.

https://doi.org/10.1016/j.gloenvcha.2006.12.006

Ali, S., Liu, Y., Ishaq, M., Shah, T., Abdullah, Ilyas, A., and Din, I. (2017). Climate Change and Its Impact on the Yield of Major Food Crops: Evidence from Pakistan. Foods, 6(6), 39. https://doi.org/10.3390/foods6060039

Arnell, N. W., Livermore, M. J. L., Kovats, S., Levy, P. E., Nicholls, R., Parry, M. L., and Gaffin, S. R. (2004). Climate and socio-economic scenarios for global-scale climate change impacts assessments: Characterising the SRES storylines. Global Environmental Change, 14(1), 3-20. https://doi.org/10.1016/j.gloenvcha.2003.10.004

Arshed, N., and Abduqayumov, S. (2016). Economic Impact of Climate Change on Wheat and Cotton in Major Districts of Punjab. Intr. J. Economics and Financial Res., 2, 183-191.

Asumadu-Sarkodie, S., and Owusu, P. A. (2016). The relationship between carbon dioxide and agriculture in Ghana: a comparison of VECM and ARDL model. Environmental Science and Pollution Research, 23(11), 10968-10982. https://doi.org/10.1007/s11356-016-6252-X

Bandara, J. S., and Cai, Y. (2014). The impact of climate change on food crop productivity, food prices and food security in South Asia. Economic Analysis and Policy, 44(4), 451-465. https://doi.org/10.1016/j.eap.2014.09.005

Barnett, T. P., Adam, J. C., and Lettenmaier, D. P. (2005). Potential impacts of a warming climate on water availability in snow-dominated regions. Nature, 438(November), 303-309. https://doi.org/10.1038/nature04141

Benhin, J. K. (2006). National Dept of Agriculture 2001. Africa.

Brown RL, Durbin J, E. J. (1975). Techniques for testing the constancy of regression relationships over time. J. The Royal Statistical Society. Series B (Methodological), 149-192.

Deressa, T. T., Hassan, R. M., and Ringler, C. (2011). Perception of and adaptation to climate change by farmers in the Nile basin of Ethiopia. J. Agricultural Science, 149(1), 23-31. https://doi.org/10.1017/S0021859610000687

Doll, P., and Siebert, S. (2002). Global modeling of irrigation water requirements. Water Resources Research, 38(4), 1-10. https://doi.org/10.1029/2001WR000355

Fatuase, A. and I. A. (2014). Perception and Adaptation to Climate Change among Farmers in Selected Communities of Ekiti State, Nigeria. FATUASE and AJIFEBUN./ JAFAG, 31(3), 101-114.

Fraiture, C. De, Smakhtin, V., Bossio, D. A., and Mccornick, P. (2007). Facing climate change by securing water for food, livelihoods and ecosystems. International Crops Research Institute for the Semi Arid Tropics, 4(1), 1-21.

Gömann, H. (2015). How Much did Extreme Weather Events Impact Wheat Yields in Germany? - A Regionally Differentiated Analysis on the Farm Level. Procedia Environmental Sciences, 29(Agri), 119-120. https://doi.org/10.1016/j.proenv.2015.07.197

Hansen, B. E. (1995). Book Reviews: Time Series Analysis. Econometric Theory, 11, 625-630. https://doi.org/10.1017/S0266466600009440

IPCC b. (2007). Summary for Policymakers: C. Current knowledge about future impacts". Climate Change 2007: Impacts, Adaptation and Vulnerability. Contribution of Working Group II to the Fourth Assessment Report of the 
Intergovernmental Panel on Climate Change [M.L. Parry. Retrieved from http://www.ipcc.ch/publications_and_data/ar4/w g2/en/spmsspm-c.html

Janjua, P. Z., Samad, G., Khan, N. U., and Nasir, M. (2010). Impact of Climate Change on Wheat Production: A Case Study of Pakistan [with Comments]. The Pakistan Development Review, 49(4), 799-822. https://doi.org/10.2307/41428691

Janjua, P. Z., Samad, G., and Khan, N. (2014). Climate change and wheat production in Pakistan: An autoregressive distributed lag approach. NJAS Wageningen J. Life Sciences, 68, 13-19. https://doi.org/10.1016/j.njas.2013.11.002

Kandlikar, M., and Risbey, J. (2000). AGRICULTURALIMPACTS OF CLIMATE CHANGE: IF ADAPTATION IS THE ANSWER,WHAT IS THE QUESTION? Climatic Change, 45, 529-539.

Kirby, J. M., Mainuddin, M., Mpelasoka, F., Ahmad, M. D., Palash, W., Quadir, M. E., ... Hossain, M. M. (2016). The impact of climate change on regional water balances in Bangladesh. Climatic Change, 135(3-4), 481-491. https://doi.org/10.1007/s10584-016-1597-1

Kurukulasuriya, P., Mendelsohn, R., Hassan, R., Benhin, J., Deressa, T., Diop, M., Dinar, A. (2006). Will African Agriculture Survive Climate Change? THE WORLD BANK ECONOMIC REVIEW, 20(3), https://doi.org/10.1093/wber/lhl004

Mahmood, N., Ahmad, B., Hassan, S., and Bakhsh, K. (2012). Impact of temperature ADN precipitation on rice productivity in rice-wheat cropping system of Punjab province. The J. Anim. and Plant Sciences, 22(4), 993-997.

Mendelsohn, R. (2014). The impact of climate change on agriculture in Asia. J. Integrative Agriculture. https://doi.org/10.1016/S2095-3119(13)60701-7

Meza, F. J., and Silva, D. (2009). Dynamic adaptation of maize and wheat production to climate change. Climatic Change, 94(1-2), 143-156. https://doi.org/10.1007/s10584-009-9544-z

Narayan, P. K., and Smyth, R. (2006). What determines migration flows from low-income to highincome countries? An empirical investigation of Fiji-U.S. migration 1972-2001. Contemporary Economic Policy, 24(2), 332-342. https://doi.org/10.1093/cep/byj019

Nkoro E, U. A. (2016). Autoregressive Distributed Lag (ARDL) cointegration technique: application and interpretation. J. Statistical and Econometric Methods, 5, 63-91.

Özdoğan, M. (2011). Modeling the impacts of climate change on wheat yields in Northwestern Turkey.
Agriculture, Ecosystems and Environment, 141(1-2), 1-12. https://doi.org/10.1016/j.agee.2011.02.001

Pesaran, M.H., Shin, Y., Smith, R. J. (2001). Bounds Testing Approaches to the Analysis of Level Relationships. J. Applied Econometrics, 16, 289-326.

Potgieter, A., Meinke, H., Doherty, A., Sadras, V. O., Hammer, G., Crimp, S., and Rodriguez, D. (2013). Spatial impact of projected changes in rainfall and temperature on wheat yields in Australia. Climatic Change, 117(1-2), 163-179. https://doi.org/10.1007/s10584-012-0543-0

Rosenzweig, C., and Parry, M. L. (1994). Potentail impact of climate change on world food supply. Nature, 367(13 January), 133-138.

Samargandi, N., Fidrmuc, J., and Ghosh, S. (2014). Is the Relationship between Financial Development and Economic Growth Monotonic? Evidence from a Sample of Middle Income Countries. CESifo Working Paper, (4743). Retrieved from http://papers.ssrn.com/sol3/papers.cfm?abstract id $=2434445$

Smadja, J., Aubriot, O., Puschiasis, O., Duplan, T., and Hugonnet, M. (2015). Climate change and water resources in the Himalayas: Field study in four geographic units of the Koshi. J. Alpine Research, 103(2), 2-22. https://doi.org/10.4000/rga.2910

Spash, C. L. (2007a). Climate Change : Need for Impacts of Global Climate Change. Economic and Political Weekly, 483-490.

Spash, C. L. (2007b). The economics of climate change impacts à la Stern: Novel and nuanced or rhetorically restricted? Ecological Economics, 63(4), 706-713. https://doi.org/10.1016/j.ecolecon.2007.05.017

Tao, F., Yokozawa, M., Xu, Y., Hayashi, Y., and Zhang, Z. (2006). Climate changes and trends in phenology and yields of field crops in China, 1981-2000. Agricultural and Forest Meteorology, 138(1-4), 82-92. https://doi.org/10.1159/000092636

Tao, F., Yokozawa, M., Liu, J., and Zhang, Z. (2008). Climate-crop yield relationships at provincial scales in China and the impacts of recent climate trends. Climate Research, 38(1), 83-94. https://doi.org/10.3354/cr00771

Tao, F., Zhang, S., and Zhang, Z. (2012). Spatiotemporal changes of wheat phenology in China under the effects of temperature, day length and cultivar thermal characteristics. European J. Agronomy, 43, 201-212. https://doi.org/ 10.1016/ j.eja. 2012.07.005

Tao, F., Zhang, Z., Xiao, D., Zhang, S., Rötter, R. P., Shi, W., ... Zhang, H. (2014). Responses of wheat 
growth and yield to climate change in different climate zones of China, 1981-2009. Agricultural and Forest Meteorology, 189-190, 91-104. https://doi.org/10.1016/j.agrformet.2014.01.013

Vermeulen, S. J., Aggarwal, P. K., Ainslie, A., Angelone, C., Campbell, B. M., Challinor, A. J., ... Wollenberg, E. (2011). Options for support to agriculture and food security under climate change. Environmental Science and Policy, 15(1), 136-144. https://doi.org/10.1016/j.envsci.2011.09.003

Webb, L. B., Whetton, P. H., and Barlow, E. W. R. (2008). Climate change and winegrape quality in Australia. Climate Research, 36(2), 99-111. https://doi.org/10.3354/cr00740
World Bank. (2012). The World Bank (WB). World Bank health nutrition and population statistics. 2012. Retrieved September 20, 2019, from http://databank.worldbank.org/data/home.aspx

You, L., Rosegrant, M. W., Wood, S., and Sun, D. (2009). Impact of growing season temperature on wheat productivity in China. Agricultural and Forest Meteorology, 149(6-7), 1009-1014. https://doi.org/10.1016/j.agrformet.2008.12.004

Yousuf, I., Ghumman, A. R., Hashmi, H. N., and Kamal, M. A. (2014). Carbon emissions from power sector in Pakistan and opportunities to mitigate those. Renewable and Sustainable Energy Reviews.

https://doi.org/10.1016/j.rser.2014.03.003. 